iso-agglutinins, blood groups and blood incompatibilities, which enabled a correct choice to be made of donors and recipients, while the use of anti-coagulants, paraffined tubes and other refinements of technique led to the adoption of the perfected method employed at the present time.

\section{The Long-term Prisoner}

IN a paper read before the ninety-fifth meeting of the American Psychiatric Association (Amer. $J$. Psychiat., 96, 1321 ; 1940) Dr. Marvin Sukov records his observations on thirty men completing life sentences in the Joliet-Stateville branch of the Illinois State Penitentiary. Their ages on admission ranged between 16 and 49, and their ages on examination were between 39 and 73 . The study was conducted by means of a questionary in which each inmate was individually interviewed for a period averaging $1 \frac{1}{4}$ hours. Dr. Sukov's conclusions were as follows: (1) Imprisonment was accompanied by progressive social severance, shown by progressive diminution in visits and correspondence in every case. (2) The patients' basic interests with regard to religion, crime and intellectual sphere were little modified by years of imprisonment. None expressed a reduction in alertness except those advanced in age, who attributed it to that cause. (3) Twenty-five who admitted their guilt stated that they had deserved punishment but that their punishment was too severe. (4) While all had a desire for freedom, many had become resigned to life imprisonment and without help would probably be unable to make an extramural adjustment. (5) Nearly all after many years imprisonment showed no antagonism to society, but none could point to a single individual as a friend.

\section{Cave Worship}

IN an interesting article in the April issue of the Hibbert Journal, Dr. R. R. Marett remarks that in addition to its mystic and religious associations the cave played no small part in early medicine, and suggests that it was primarily as a hydropathic establishment that the cave found so much favour with the sick. In the cave of Aesculapius, mentioned by Pausanias, for example, the healing waters gushed out from a rock, and at Elis in the cave of the Anigrid nymphs he states that a leper must sacrifice before bathing in the neighbouring river in order to leave his "shame" there. There were also caves mentioned by Pausanias of which the efficacy had possibly nothing to do with water, such as the cave of Aphrodite. Moreover, the famous Lemnian earth or terra sigillata which was supposed to provide an antidote to snake-poisoning was obtained from a cave.

\section{The Government Museum, Madras}

UNDER the superintendence of Dr. F. H. Gravely, an important extension to the Government Museum, Madras, has been completed and opened to the public, following the plans of the late R. Dann, consulting architect to that Government. The new building has provided accommodation for the staff of curators, the block which they formerly occupied being now given up to the zoological collections. But its main function is to give suitable expression to the evolution of the decorative motives of the architecture of the magnificent temples of South India. For the Tamil country, these changes form an interesting and logical sequence. The temples of other parts of India differ from those of Tamil origin, and although the development of their architecture is not yet fully understood, attempts have been made in the new building to indicate the succession of changes. A short account of these arrangements, based upon Dr. Gravely's address at the opening ceremony, which was performed by His Excellency the Governor of Madras, Lord Erskine, appears in the July number of the Museums Journal (40, 109 ; 1940).

\section{Nematode Parasites of Plants}

A catalogue of nematode parasites of plants, compiled by Dr. T. Goodey has been issued by the Imperial Bureau of Agricultural Parasitology, St. Albans, price 10s. The work consists of an alphabetical list of the scientific names of all plants which have been reported as hosts of nematodes, comprising more than 2,000 species and varieties of flowering plants, 78 ferns, 55 mosses, 5 liverworts and 3 seaweeds. In each case the appropriate parasite or parasites is stated, together with the name of the first recorder and the date of the record. For convenience, an alphabetical list of the popular plant names, with the scientific name appended, is also supplied, so that the reader can be sure of finding the information he requires by whichever plant name is the more familiar to him. The publication concludes with a list of references relevant to the records cited. Usually this is the earliest record obtainable, but in a few cases a more accessible reference has been deliberately selected.

\section{Announcements}

The Home Secretary has announced in the House of Commons that he is willing to consider steps to enable alien men of science who are not released to carry on their scientific activities or studies in internment.

The following appointments in the Colonial Service have recently been made: F. R. Bell, veterinary officer, Uganda; J. H. Hughes, assistant conservator of forests, British Guiana; R. M. Shackleton, geologist (temporary), Kenya.

A FURTher step in the mobilization of the manpower of Great Britain is marked by the issue of the first industrial registration order made by the Minister of Labour. Registers have already been made of professional engineers, chemists and physicists and quantity surveyors. The new order requires the registration of skilled men more than twenty-one years old in certain specified occupations, mainly engineering, who are not employed on Government work. The five days of registration, to which also the test of full employment on Government work applies, are August 19-23. 